\title{
DESVIOS E ENGAJAMENTOS EM PROCESSOS COLETIVOS DE DESIGN COLABORATIVO
}

\author{
AUTOR: BRENO DOS SANTOS FRANCA \\ CO-AUTOR/ORIENTADOR: MARCELO SIMON WASEM
}

Resumo: O presente trabalho apresenta experiências e reflexões acerca de uma abordagem do design com ênfase em processos colaborativos realizado com movimentos e coletivos que trabalham com arte, cultura e resistências políticas, dialogando com o entorno a partir da Universidade Federal do Sul da Bahia (UFSB). O foco da pesquisa foi desenvolver atividades de criação de identidades visuais através de metodologias experimentais colaborativas com grupos diversos, pelo projeto de pesquisa "D.E.L.I.R.A.: Ações em Arte Pública - Práticas em Artes Visuais e Design". Procurou-se pensar o design como espaço de criação e aprendizado processual, enfatizando o dinamismo colaborativo entre as duas partes - cliente e designer - para além do habitual. Assim, criou-se uma relação artística-colaborativa que foge do viés mercadológico do design gráfico.

Essa metodologia colaborativa, que variou de acordo com as particularidades de cada coletivo, pode ser visualizada e compreendida nos seguintes projetos: "Travessias... Ciclos Transatlânticos", "ILUMILUTAS", "Observatório de Dramaturgias" e "D.E.L.I.R.A.". Dessa forma os projetos de design realizados pelo projeto de pesquisa, por servirem às propostas acadêmicas de grupos marginalizados (como coletivos que trabalham com arte, com questões de transgeneridade e afrodiaspóricas, artísticos, negros), acabam por se enquadrarem na construção de um design de resistência e para resistências. Ao buscar novos métodos de fazer design, podemos compreender que a abertura dos processos e a dinâmica do pensar, ao se tornarem mais importantes que o produto final do design, como afirma Marcos Beccari, os transforma de meros objetivos em vivências de design ressignificadas a partir de dentro.

Palavras-chave: Design gráfico, colaboração, identidade visual, design e política. 